\title{
Review on optimization of CNC Turning Process Parameters for Surface Roughness and Material Removal Rate Using Taguchi, GRA, and RSM Approaches
}

\author{
D.O.I - 10.51201/Jusst12657 \\ http://doi.org/10.51201/Jusst12657 \\ "Neeraj, Sukhdeep S. Dhami" \\ "Mechanical Engineering Department, NITTTR, Chandigarh-160019, India" \\ "Mechanical Engineering Department, NITTTR, Chnadigarh-160019, India"
}

\begin{abstract}
Nowadays, the realization of a fine surface finish is the main objective of the metal cutting industry during the turning processes. This work consists of an analysis of the work carried out by the researchers in the field of filming process parameters, to Examine the impact of speed, cutting speed (feed), and depth of cut in a computer numeric control machine. This study will provide insight into current trends research in the area of Taguchi, Grey Relational Analysis, Response Surface Method, ANOVA \& CNC Turning.
\end{abstract}

Keywords: CNC Machine, Taguchi, ANOVA, GRA

\section{Introduction}

CNC turning is the first broad machine used for the manufacture of diametrically shaped parts in less time, featuring a better surface finish and high material removal rate exact dimensions as well. It is very much desired that the result of having a good surface finish and high material removal rate be made in a short time. The quality of the surface finish of a product is generally determined as a function of the surface roughness measured. Surface roughness typically hangs on such cutting parameters as speed, feed, and depth of cut.

Choosing the right management factors for the experience is very important to provide the parts with better surface end and high material removal rate in a brief time. Over the past couple of decades, a lot of work has been done to raise the standard of the commodity and power in machining. The still diverse aspects of this paper constitute a unit to be explored. 


\section{Literature Review}

\begin{tabular}{|c|c|c|c|c|c|c|}
\hline Year \& Author & $\begin{array}{c}\text { Aim of Research } \\
\text { Work }\end{array}$ & Material & $\begin{array}{c}\text { Input } \\
\text { Parameters }\end{array}$ & $\begin{array}{c}\text { Output } \\
\text { Parameter }\end{array}$ & $\begin{array}{l}\text { Technique } \\
\text { Used }\end{array}$ & Result Observed \\
\hline R. Viswanathan et al. (2020) & $\begin{array}{l}\text { Optimization of turning } \\
\text { parameters for } \\
\text { magnesium alloy }\end{array}$ & $\begin{array}{l}\text { Mg alloy } \\
\text { AZ91D }\end{array}$ & $\begin{array}{l}\text { Cutting speed, } \\
\text { Feed, \& Depth of } \\
\text { cut }\end{array}$ & $\begin{array}{l}\text { Flank wear, } \\
\text { Surface roughness, } \\
\text { Cutting force } \& \\
\text { Material removal } \\
\text { rate }\end{array}$ & $\begin{array}{l}\text { Taguchi, GRA, } \\
\text { PCA }\end{array}$ & $\begin{array}{l}\text { The most dominating parameter on } \\
\text { the multiple performances was } \\
\text { found to be the depth of cut. }\end{array}$ \\
\hline $\begin{array}{l}\text { S. Dhanalakshmi\& T. } \\
\text { Rameshbabu (2020) }\end{array}$ & $\begin{array}{l}\text { Optimization of } \\
\text { Process Parameters in } \\
\text { CNC Turning of LM } \\
25 \text { Alloy Using the } \\
\text { Taguchi-Grey } \\
\text { Approach }\end{array}$ & $\begin{array}{l}\text { LM } 25 \\
\text { Aluminum } \\
\text { Alloy }\end{array}$ & $\begin{array}{l}\text { Cutting speed, } \\
\text { Feed, Depth of cut } \\
\text { \& Cutting fluid } \\
\text { flow rate }\end{array}$ & $\begin{array}{l}\text { Surface roughness, } \\
\text { Material removal } \\
\text { rate \& Total } \\
\text { machining cost }\end{array}$ & $\begin{array}{l}\text { Taguchi, GRA, } \\
\text { ANOVA }\end{array}$ & $\begin{array}{l}\text { Depth of cut is predominating } \\
\text { variable for MRR, and feed \& } \\
\text { cutting speed predominating } \\
\text { variable for SR and TMC }\end{array}$ \\
\hline S.P. Palaniappan et al. (2020) & $\begin{array}{l}\text { process parameters } \\
\text { optimization on } \\
\text { Aluminum } 6082 \text { alloy }\end{array}$ & $\begin{array}{l}\text { Aluminum } \\
\quad 6082\end{array}$ & $\begin{array}{l}\text { Spindle speed, } \\
\text { Feed \& DOC }\end{array}$ & $\begin{array}{l}\text { Surface roughness } \\
\& \text { Material } \\
\text { removal rate }\end{array}$ & $\begin{array}{l}\text { Taguchi, } \\
\text { ANOVA }\end{array}$ & $\begin{array}{l}\text { significant parameter for MRR } \\
\text { was speed \& feed was the most } \\
\text { significant parameter for SR. }\end{array}$ \\
\hline Ning Li et al. (2019) & $\begin{array}{l}\text { Multi Response } \\
\text { optimization }\end{array}$ & Ti-6Al-4V & $\begin{array}{c}\text { Insert Type, Feed } \\
\& \text { DOC }\end{array}$ & $\begin{array}{l}\text { Radial thrust force, } \\
\text { Cutting power \& } \\
\text { Coefficient of } \\
\text { friction }\end{array}$ & GRA, KPCA & $\begin{array}{l}\text { Feed rate has the most dominant } \\
\text { effect on thrust force \& e depth of } \\
\text { cut is the most } \\
\text { the significant factor for cutting } \\
\text { power and coefficient of friction }\end{array}$ \\
\hline A.Saravanakumar et al. (2018) & $\begin{array}{l}\text { Optimization of CNC } \\
\text { Turning Parameters }\end{array}$ & $\begin{array}{l}\text { Aluminum } \\
6063\end{array}$ & $\begin{array}{l}\text { Speed, feed \& } \\
\text { DOC }\end{array}$ & Surface roughness & Taguchi & $\begin{array}{l}\text { The feed is the major influencing } \\
\text { parameters among the three } \\
\text { controllable factors }\end{array}$ \\
\hline $\begin{array}{l}\text { Suneel Kumar Rathore et al. } \\
\text { (2018) }\end{array}$ & $\begin{array}{l}\text { Determination of } \\
\text { optimum parameters in } \\
\text { CNC turning }\end{array}$ & $\begin{array}{l}\text { Aluminum } \\
6463\end{array}$ & $\begin{array}{l}\text { Spindle speed, } \\
\text { feed, DOC \& } \\
\text { Coolant }\end{array}$ & Surface roughness & GRA, PCA & $\begin{array}{l}\text { Quantitative involvements of the } \\
\text { different factors are } 15.33 \% \text { of } \\
\text { SS, } 3.06 \% \text { of FR, } 0.40 \% \text { of Doc, } \\
\text { and } 30.87 \% \text { of coolant } \\
\text { respectively. }\end{array}$ \\
\hline Vijay Kumar et al. (2018) & $\begin{array}{l}\text { Optimization of } \\
\text { Machining Parameters } \\
\text { in CNC Turning }\end{array}$ & SS (EN19) & $\begin{array}{l}\text { Lubrication, feed, } \\
\text { DOC \& spindle } \\
\text { speed }\end{array}$ & SR \& MRR & Taguchi & $\begin{array}{l}\text { MRR increase with the increase in } \\
\text { feed \& SR decrease with increase } \\
\text { in DOC \& speed }\end{array}$ \\
\hline Bikram Jit Singh et al. (2017) & $\begin{array}{c}\text { Parametric } \\
\text { optimization of CNC } \\
\text { turning }\end{array}$ & Al 7020 & $\begin{array}{l}\text { Cutting speed, } \\
\text { feed \& DOC }\end{array}$ & SR \& MRR & RSM & $\begin{array}{l}\text { Best turning parameters found for } \\
\text { maximum MRR and minimum SR } \\
\text { are:- cutting speed = } 167 \mathrm{~m} / \mathrm{min}, \\
\text { feed }=0.1 \mathrm{~mm} / \mathrm{rev} \text { and depth of cut } \\
=2.0 \mathrm{~mm}\end{array}$ \\
\hline $\begin{array}{l}\text { M. Nataraj\& K. } \\
\text { Balasubramanian (2017) }\end{array}$ & $\begin{array}{l}\text { Parametric } \\
\text { optimization of } \mathrm{CNC} \\
\text { turning process }\end{array}$ & $\begin{array}{l}\text { LM6 aluminum } \\
\text { alloy }\end{array}$ & $\begin{array}{l}\text { Cutting speed, } \\
\text { feed \& DOC }\end{array}$ & $\begin{array}{l}\text { Work-tool } \\
\text { interface } \\
\text { temperature, SR \& } \\
\text { Vibration }\end{array}$ & ANOVA & $\begin{array}{l}\text { Feed was the major contributor for } \\
\text { vibration \& Doc and cutting speed } \\
\text { were the major contributors to } \\
\text { surface roughness. }\end{array}$ \\
\hline
\end{tabular}




\begin{tabular}{|c|c|c|c|c|c|c|}
\hline Franko Puh et al. (2016) & $\begin{array}{l}\text { OPTIMIZATION OF } \\
\text { MACHINING } \\
\text { PARAMETERS FOR } \\
\text { TURNING } \\
\text { OPERATION }\end{array}$ & $\begin{array}{l}\text { Carbon steel } \\
\text { Ck45 }\end{array}$ & $\begin{array}{l}\text { Cutting speed, } \\
\text { feed \& DOC }\end{array}$ & SR \& MRR & GRA & $\begin{array}{l}\text { Surface roughness and material } \\
\text { removal at cutting speed of } \mathrm{V}= \\
400 \mathrm{~m} / \mathrm{min} \text {, feed rate of } \mathrm{f}=0,1 \\
\mathrm{~mm} / \mathrm{rev} \text { and depth of cut } \mathrm{d}=1,2 \\
\mathrm{~mm} \text { are significant }\end{array}$ \\
\hline R Rudrapati et al. (2016) & $\begin{array}{l}\text { Optimization of } \\
\text { process parameters in } \\
\text { CNC turning }\end{array}$ & $\begin{array}{l}\text { Aluminum } \\
\text { Alloy }\end{array}$ & $\begin{array}{l}\text { Spindle speed, } \\
\text { feed rate \& DOC }\end{array}$ & SR & RSM \& TLBO & $\begin{array}{l}\text { Optimal parametric condition } \\
\text { spindle speed }=700 \mathrm{rpm} \text {, feed rate } \\
=25 \mathrm{~mm} / \mathrm{min} \text { and depth of cut }= \\
0.2 \mathrm{~mm} \text { and } \\
\text { corresponding surface roughness is } \\
0.42081 \mu \mathrm{m} .\end{array}$ \\
\hline Singh MK et al. (2015) & $\begin{array}{l}\text { Optimization of } \\
\text { Process Parameters on } \\
\text { CNC lathe }\end{array}$ & Al-6082 T-6 & $\begin{array}{l}\text { Feed, speed \& } \\
\text { DOC }\end{array}$ & SR & Taguchi & $\begin{array}{l}\text { Depth of Cut had minimum impact } \\
\text { on Surface Roughness contributing } \\
16.27 \%\end{array}$ \\
\hline Murat Sarıkaya et al. (2015) & $\begin{array}{c}\text { Multi-response } \\
\text { optimization of MQL } \\
\text { parameters }\end{array}$ & Haynes 25 & $\begin{array}{l}\text { Cutting fluid, flow } \\
\text { rate \& cutting } \\
\text { speed }\end{array}$ & TWR, SR & GRA & $\begin{array}{l}\text { MQL parameters like cutting } \\
\text { speed, cutting fluid, and flow are } \\
\text { the significant factors affecting } \\
\text { tool wear and surface roughness }\end{array}$ \\
\hline Murat Sarıkaya et al. (2014) & $\begin{array}{l}\text { Analysis of machining } \\
\text { parameters in CNC } \\
\text { turning }\end{array}$ & AISI 1050 & $\begin{array}{l}\text { Cutting speed, } \\
\text { feed \& DOC }\end{array}$ & SR & $\begin{array}{l}\text { Taguchi \& } \\
\text { RSM }\end{array}$ & $\begin{array}{l}\text { Feed rate and the cooling condition } \\
\text { have the highest influence on } \\
\text { machined surface roughness. }\end{array}$ \\
\hline $\begin{array}{l}\text { K. Chandrasekaran et al. } \\
\text { (2013) }\end{array}$ & $\begin{array}{l}\text { Prediction Model for } \\
\text { CNC Turning }\end{array}$ & AISI316 & $\begin{array}{l}\text { Cutting speed, } \\
\text { feed \& DOC }\end{array}$ & SR \& TWR & RSM & $\begin{array}{l}\text { The response surface model for SR } \\
\text { and TW are developed from the } \\
\text { observed data the predicted and } \\
\text { measured values are fairly close, }\end{array}$ \\
\hline $\begin{array}{l}\text { IlhanAsiltürk\&SüleymanNeseli } \\
\text { (2012) }\end{array}$ & $\begin{array}{l}\text { Multi response } \\
\text { optimization of CNC } \\
\text { turning parameters }\end{array}$ & AISI 304 & $\begin{array}{l}\text { Cutting speed, } \\
\text { feed \& DOC }\end{array}$ & SR & $\begin{array}{l}\text { Taguchi \& } \\
\text { RSM }\end{array}$ & $\begin{array}{l}\text { Both Taguchi and response surface } \\
\text { statistical analyses indicated that } \\
\text { the main effect of the feed rate is } \\
\text { the most significant factor on the } \\
\text { workpiece surface roughness }\end{array}$ \\
\hline $\begin{array}{l}\text { S. Ranganathan\& T. } \\
\text { Senthilvelan (2011) }\end{array}$ & $\begin{array}{l}\text { Multi-response } \\
\text { optimization of } \\
\text { machining parameters } \\
\text { in hot turning }\end{array}$ & $\begin{array}{l}\text { stainless steel } \\
\text { (type 316) }\end{array}$ & $\begin{array}{l}\text { Cutting speed, } \\
\text { feed, DOC } \\
\text { \&workpiece } \\
\text { temperature }\end{array}$ & $\begin{array}{l}\text { SR, MRR \& Tool } \\
\text { life }\end{array}$ & GRA & $\begin{array}{l}\text { cutting speed at } 113.1 \mathrm{~m} / \mathrm{min} \text {, feed } \\
\text { rate at } 0.381 \mathrm{~mm} / \mathrm{rev} \text {, and } \\
\text { workpiece temperature at } 400^{\circ} \mathrm{C} \\
\text { will give the optimum results for } \\
\text { hot turning }\end{array}$ \\
\hline Aman Aggarwal et al. (2008) & $\begin{array}{l}\text { Optimizing power } \\
\text { consumption for CNC } \\
\text { turned parts }\end{array}$ & AISI P-20 & $\begin{array}{l}\text { Cutting speed, } \\
\text { feed, DOC, } \\
\text { Environment \& } \\
\text { Nose Radius }\end{array}$ & $\begin{array}{c}\text { Power } \\
\text { Consumption }\end{array}$ & $\begin{array}{l}\text { Taguchi \& } \\
\text { RSM }\end{array}$ & $\begin{array}{l}\text { Taguchi's technique revealed that } \\
\text { cryogenic environment is the most } \\
\text { significant factor \& RSM also } \\
\text { revealed that cryogenic } \\
\text { environment has very } \\
\text { significant effect in reducing } \\
\text { power consumption. }\end{array}$ \\
\hline
\end{tabular}




\section{Conclusion}

In this work, the researchers performed studies on process parameters such as spindle speed, feed, depth of cut, environment, nose radius, and the impact on surface roughness, material removal rate, power consumption, tool wear rate, and thrust force.

\section{References}

1. Viswanathan, R., Ramesh, S., Maniraj, S., and Subburam, V., 2020. Measurement and multi-response optimization of turning parameters for magnesium alloy using hybrid combination of Taguchi-GRA-PCA technique. Measurement, 159, p.107800.

2. Dhanalakshmi, S. and Rameshbabu, T., 2020. Multi-Aspects optimization of process parameters in CNC turning of LM 25 alloy using the Taguchi-Grey approach. Metals, 10(4), p.453.

3. Palaniappan, S.P., Muthukumar, K., Sabariraj, R.V., Kumar, S.D. and Sathish, T., 2020. CNC Turning process parameters optimization on Aluminium 6082 alloy by using Taguchi and ANOVA. Materials Today: Proceedings, 21, pp.1013-1021.

4. Li, N., Chen, Y.J. and Kong, D.D., 2019. Multi-response optimization of Ti-6Al-4V turning operations using Taguchi-based grey relational analysis coupled with kernel principal component analysis. Advances in Manufacturing, 7(2), pp.142-154.

5. Saravanakumar, A., Karthikeyan, S.C. and Dhamotharan, B., 2018. Optimization of CNC Turning Parameters on Aluminum Alloy 6063 using TaguchiRobust Design. Materials Today: Proceedings, 5(2), pp.8290-8298.

6. Rathore, S.K., Vimal, J. and Kasdekar, D.K., 2018. Determination of optimum parameters for surface roughness in CNC turning by using GRA-PCA. International Journal of Engineering, Science and Technology, 10(2), pp.37-49.

7. Kumar, M. V., Kumar, B. K., \&Rudresha, N. (2018). Optimization of machining parameters in CNC turning of stainless steel (EN19) by Taguchi's orthogonal array experiments. Materials Today: Proceedings, 5(5), 11395-11407.

8. Nayak, N.K. and SODHI, H.S., 2017. Optimization of Cnc Turning Parameters for Al-6061 Using Response Surface Methodology. International Journal of Mechanical and Production Engineering Research and Development (IJMPERD), 7(4), pp.127-138.

9. Nataraj, M. and Balasubramanian, K., 2017. Parametric optimization of CNC turning process for hybrid metal matrix composite. The International Journal of Advanced Manufacturing Technology, 93(1), pp.215224.

10. Puh, F., Jurkovic, Z., Perinic, M., Brezocnik, M. and Buljan, S., 2016. Optimization of machining parameters for turning operation with multiple quality characteristics using Grey relational analysis. Tehničkivjesnik, 23(2), pp.377-382.

11. Rudrapati, R., Sahoo, P. and Bandyopadhyay, A., 2016, September. Optimization of process parameters in CNC turning of aluminium alloy using hybrid RSM cum TLBO approach. In IOP conference series: materials science and engineering (Vol. 149, No. 1, p. 012039). IOP Publishing.

12. Singh, M.K., Chauhan, D., Gupta, M.K. and Diwedi, A., 2015. Optimization of process parameters of aluminum alloy (Al-6082 T-6) machined on CNC lathe machine for low surface roughness. $J$ Mater SciEng, 4(6), pp.2169-0022.

13. Sarıkaya, M. and Güllü, A., 2015. Multi-response optimization of MQL parameters using Taguchi-based GRA in turning of difficult-to-cut alloy Haynes 25. J Clean Prod, 91(15), pp.347-357.

14. Sarıkaya, M., \&Güllü, A. (2014). Taguchi design and response surface methodology based analysis of machining parameters in CNC turning under MQL. Journal of Cleaner Production, 65, 604-616.

15. Raja, K., Marimuthu, P. and Chandrasekaran, K., 2013. Prediction model for cnc turning on aisi316 with single and multilayered cutting tool using box behnken design (research note). International Journal of Engineering, 26(4), pp.401-410.

16. Asiltürk, I. and Neşeli, S., 2012. Multi response optimisation of CNC turning parameters via Taguchi method-based response surface analysis. Measurement, 45(4), pp.785-794.

17. Ranganathan, S. and Senthilvelan, T., 2011. Multi-response optimization of machining parameters in hot turning using grey analysis. The International Journal of Advanced Manufacturing Technology, 56(5-8), pp.455-462.

18. Aggarwal, A., Singh, H., Kumar, P., \& Singh, M. (2008). Optimizing power consumption for CNC turned parts using response surface methodology and Taguchi's technique - a comparative analysis. Journal of materials processing technology, 200(1-3), 373-384. 